\title{
Increased serum potassium affects renal outcomes: a post hoc analysis of the Reduction of Endpoints in NIDDM with the Angiotensin II Antagonist Losartan (RENAAL) trial
}

\author{
Y. Miao • D. Dobre • H. J. Lambers Heerspink • \\ B. M. Brenner • M. E. Cooper • H-H. Parving • \\ S. Shahinfar • D. Grobbee • D. de Zeeuw
}

Received: 24 June 2010 / Accepted: 1 September 2010 / Published online: 30 September 2010

(C) The Author(s) 2010. This article is published with open access at Springerlink.com

\begin{abstract}
Aims/hypothesis To assess the effect of an angiotensin receptor blocker (ARB) on serum potassium and the effect of a serum potassium change on renal outcomes in patients with type 2 diabetes and nephropathy.

Methods We performed a post hoc analysis in patients with type 2 diabetes participating in the Reduction of Endpoints in
\end{abstract}

Y. Miao $\cdot$ D. Dobre $\cdot$ H. J. Lambers Heerspink $(\bowtie) \cdot$ D. de Zeeuw Department of Clinical Pharmacology,

University Medical Centre Groningen,

Antonius Deusinglaan 1,

9713 AV Groningen, the Netherlands

e-mail: h.j.lambers.heerspink@med.umcg.nl

\section{B. M. Brenner}

Brigham and Women's Hospital and Harvard School of Medicine, Boston, MA, USA

M. E. Cooper

Baker IDI Heart and Diabetes Research Institute,

Melbourne, VIC, Australia

H.-H. Parving

Department of Medical Endocrinology,

University Hospital of Copenhagen,

Copenhagen, Denmark

H.-H. Parving

The Faculty of Health Science, Aarhus University,

Aarhus, Denmark

S. Shahinfar

Shahinfar Consulting, The Children's Hospital of Philadelphia,

Philadelphia, PA, USA

D. Grobbee

Julius Center for Health Science and Primary Care,

University Medical Center Utrecht,

Utrecht, the Netherlands
NIDDM with the Angiotensin II Antagonist Losartan (RENAAL) study. Renal outcomes were defined as a composite of doubling of serum creatinine or end-stage renal disease. Results At month 6, 259 (38.4\%) and 73 (10.8\%) patients in the losartan group and $151(22.8 \%)$ and $34(5.1 \%)$ patients in the placebo group had serum potassium $\geq 5.0 \mathrm{mmol} / 1$ and $\geq 5.5 \mathrm{mmol} / \mathrm{l}, \quad(p<0.001)$, respectively. Losartan was an independent predictor for serum potassium $\geq 5.0 \mathrm{mmol} / \mathrm{l}$ at month 6 (OR 2.8; 95\% CI 2.0-3.9). Serum potassium at month $6 \geq 5.0 \mathrm{mmol} / \mathrm{l}$ was in turn associated with increased risk for renal events (HR 1.22; 95\% CI 1.00-1.50), independent of other risk factors. Adjustment of the overall treatment effects for serum potassium augmented losartan's renoprotective effect from $21 \%(6-34 \%)$ to $35 \%(20-48 \%)$, suggesting that the renoprotective effects of losartan are offset by its effect on serum potassium.

Conclusions/interpretation In this study, we found that treatment with the ARB losartan is associated with a high risk of increased serum potassium levels, which is in turn associated with an increased risk of renal outcomes in patients with diabetes and nephropathy. Whether additional management of high serum potassium would further increase the renal protective properties of losartan is an important clinical question.

Keywords Angiotensin receptor blocker Losartan . Nephropathy Potassium $\cdot$ Type 2 diabetes

$\begin{array}{ll}\text { Abbreviations } \\ \text { ACR } & \text { Albumin:creatinine ratio } \\ \text { ARB } & \text { Angiotensin receptor blocker } \\ \text { CV } & \text { Cardiovascular } \\ \text { DSCR } & \text { Doubling of serum creatinine } \\ \text { ESRD } & \text { End-stage renal disease }\end{array}$


eGFR Estimated glomerular filtration rate

NIDDM Non-insulin-dependent diabetes mellitus

RAAS Renin-angiotensin-aldosterone system

RENAAL Reduction of Endpoints in NIDDM with the Angiotensin II Antagonist Losartan

\section{Introduction}

Diabetic nephropathy is the leading cause of end-stage renal disease (ESRD) in western societies. As the prevalence of diabetes is increasing, ESRD accounts for substantial morbidity and mortality $[1,2]$.

Angiotensin receptor blockers (ARBs) have several important beneficial effects in patients with diabetes and nephropathy, such as decreasing systemic blood pressure and reducing albuminuria. These effects are related to longterm renal protection [3, 4]. However, these beneficial effects are accompanied by a so-called side effect of ARBs, induction of a rise in serum potassium levels even leading to hyperkalaemia. This situation may in turn lead to detrimental long-term effects [5]. The risk of hyperkalaemia is particularly high in patients with diabetes as these patients already have reduced aldosterone production secondary to renin deficiency, the so-called hyporeninemic hypoaldosteronism syndrome [6, 7]. Diabetes, low renal function and use of renin-angiotensin-aldosterone system (RAAS) inhibitors are independent factors that increase serum potassium level. In combination, these factors pose patients at even higher risk of hyperkalaemia [8].

Increased serum potassium levels are associated with increased risk for cardiovascular $(\mathrm{CV})$ morbidity and mortality. Hyperkalaemia as a result of ARB therapy has been related to worse $\mathrm{CV}$ outcomes [9]. However, the relationship between change in serum potassium levels in response to RAAS therapy and renal outcomes is not well established. Therefore, we assessed the relationship between ARB treatment, serum potassium levels and renal outcomes in patients with type 2 diabetes and nephropathy participating in the Reduction of Endpoints in NIDDM with the Angiotensin II Antagonist Losartan (RENAAL) trial (Clinical trials.gov identifier: NCT 00308347).

\section{Methods}

Study design The RENAAL trial was a multinational, randomised, double-blind trial that compared the effects of losartan vs placebo in addition to conventional antihypertensive medication in patients with type 2 diabetes and nephropathy. Patients had serum creatinine levels between 115 and $265 \mu \mathrm{mol} / 1$ (133 to $265 \mu \mathrm{mol} / \mathrm{l}$ for men weighing more than $60 \mathrm{~kg}$ ). The study was performed in
250 centres in 28 countries and involved 1,513 patients. The study design, the inclusion/exclusion criteria, and the treatment protocol have been reported previously $[3,10]$. In short, after a 6-week screening phase, patients were randomised to either losartan $50 \mathrm{mg}$ (titrated to $100 \mathrm{mg}$ after 4 weeks) or placebo. Additional antihypertensive medications (calcium channel blockers, $\beta$-blockers, centrally acting agents, and diuretics, excluding angiotensinconverting enzyme inhibitors or other angiotensin receptor antagonists) were permitted to reach the blood pressure goal of $<140 / 90 \mathrm{mmHg}$ (systolic/diastolic). All patients signed informed consent before enrolment, and the local Institutional Review Board of each participating centre approved the study. The mean duration of follow-up was 3.4 years. Blood pressure, serum potassium level, serum creatinine and albumin:creatinine ratio were measured at first month, third month, and then every 3 months until the end of the study.

Change in serum potassium and outcomes In this study, we performed a post hoc analysis of all individuals with potassium measurements included in the RENAAL trial. We assessed the relationship between serum potassium level and renal outcomes in two ways. First, we assessed the relationship between serum potassium and renal outcomes at month 6 . The month 6 values were chosen as the treatment effects were considered to be fully present and relatively few renal events occurred before month 6 . The month 6 serum potassium level was classified into two categories: $<5.0 \mathrm{mmol} / 1$ (reference, and $\geq 5.0 \mathrm{mmol} / 1$ [11]. We selected this threshold (instead of the clinical accepted value of $5.5 \mathrm{mmol} / \mathrm{l}$ ) because the risk of adverse renal outcomes started to increase from $5.0 \mathrm{mmol} / \mathrm{l}$, and a small number of patients reached serum potassium levels $\geq 5.5 \mathrm{mmol} / \mathrm{l}$ in our population. As a single elevated potassium measurement may be an erroneous finding, we also assessed the relationship between persistent druginduced serum potassium at months 6 and 9 and its association with renal outcome. These individuals were either compared with those with a single elevated serum potassium measurement at month 6 or 9 , or compared with those without increases in serum potassium above $5.0 \mathrm{mmol} / \mathrm{l}$ during the first 9 months of follow-up.

In the second approach, we calculated the average serum potassium concentration during follow-up and explored the relationship between the average serum potassium level during follow-up with renal outcomes. The average serum potassium concentration, as well as average levels of other relevant covariates was calculated as the mean of the first month and each consecutive third month potassium value until the occurrence of the renal event. This approach was chosen as it more accurately reflects the risk of a participant to exposure to a high serum potassium load for a definite period of time than a single elevated measure. Renal out- 
comes were defined as a composite of doubling of serum creatinine (DSCR) or ESRD, and as DSCR and ESRD individually. All endpoints were adjudicated by a blinded endpoint committee using rigorous guideline definitions.

Statistical analysis Differences among patient subgroups were evaluated by using chi-squared test or $t$ test, as appropriate. Mean serum potassium level at each visit during follow-up, as well as the proportion of patients with month 6 potassium level $\geq 5.0 \mathrm{mmol} / 1$ and $\geq 5.5 \mathrm{mmol} / 1$ was calculated in both the losartan and placebo group. To identify the predictors of increased serum potassium at month 6, a multivariate logistic regression model was used. Baseline characteristics that showed an association with serum potassium $\geq 5.0 \mathrm{mmol} / 1(p<0.2)$ at univariate analysis were selected for the multivariate logistic model. The multivariate logistic model was adjusted for age, treatment assignment, serum potassium, diastolic blood pressure, estimated glomerular filtration rate (eGFR), month 6 change in eGFR from baseline, urinary albumin:creatinine ratio (ACR), prescription of $\alpha$-blockers, thiazide diuretics, loop diuretics, and haemoglobin. To assess the association between change in serum potassium from baseline to month 6 and renal outcomes, a multivariate Cox proportional hazard model was used. The linearity of baseline and followup continuous variables was assessed. If the linearity was not demonstrated, the variable was recoded as a categorical variable. In the final Cox model we adjusted for the following baseline variables: age, sex, race, treatment, eGFR, follow-up systolic blood pressure, diastolic blood pressure, ACR. We checked for an interaction between serum potassium levels at month 6 and eGFR. To ensure that our results are not affected by baseline renal function and other important predictors of renal outcomes, such as blood pressure and urinary albumin excretion we performed a sensitivity analysis in which we matched patients based on their propensity score of developing serum potassium $\geq 5.0 \mathrm{mmol} / \mathrm{l}$. The propensity score was obtained by performing a logistic regression model with serum potassium $\geq 5.0 \mathrm{mmol} / 1$ as an outcome. The risk of renal outcomes was presented by hazard ratios (HR) with $95 \%$ confidence intervals $(95 \% \mathrm{CI})$. Analyses were conducted with SPSS version 16.0 software.

\section{Results}

Serum potassium over time and characteristics of the study population In the whole population at month 6, 928 (69.4\%) patients had a serum potassium $<5.0 \mathrm{mmol} /$ 1 (normal value) while $410(30.6 \%)$ patients had month 6 serum potassium $\geq 5.0 \mathrm{mmol} / \mathrm{l}$ (Table 1$)$. In the losartan group, mean potassium level significantly increased from $4.59 \mathrm{mmol} / \mathrm{l}$ at baseline to $4.79 \mathrm{mmol} / \mathrm{l}$ at month 6 , and
Table 1 Baseline and month 6 characteristics of the whole population ${ }^{\mathrm{a}}$

\begin{tabular}{|c|c|c|}
\hline \multirow[b]{2}{*}{ Baseline characteristic } & \multicolumn{2}{|c|}{ Serum potassium at month $6(\mathrm{mmol} / \mathrm{l})$} \\
\hline & $<5.0(n=928)$ & $\geq 5.0 \mathrm{mmol} / 1(n=410)$ \\
\hline Age ( years) & $60.0(7.6)$ & $60.4(7.1)$ \\
\hline Male, $n(\%)$ & $593(63.9)$ & $248(60.5)$ \\
\hline \multicolumn{3}{|l|}{ Race, $n(\%)$} \\
\hline White & 449 (48.4) & $198(48.3)^{\dagger}$ \\
\hline Black & $161(17.3)$ & $40(9.8)$ \\
\hline Hispanic & $144(15.5)$ & $98(23.9)$ \\
\hline Asian & $163(17.6)$ & $68(16.6)$ \\
\hline Other & $11(1.2)$ & $6(1.5)$ \\
\hline Systolic BP (mmHg) & $152.1(19.2)$ & $153.2(19.7)$ \\
\hline Diastolic BP (mmHg) & $82.9(10.5)$ & $81.3(10.1)^{\mathrm{b}}$ \\
\hline $\begin{array}{l}\text { Urinary ACR (mg/mmol), } \\
\text { median (IQR) }\end{array}$ & $129(59-263)$ & $155(76-327)^{\mathrm{b}}$ \\
\hline Serum creatinine $(\mu \mathrm{mol} / \mathrm{l})$ & $161(41.6)$ & $173(42.9)^{\mathrm{b}}$ \\
\hline eGFR $\left(\mathrm{mlmin}^{-1} 1.73 \mathrm{~m}^{-2}\right)$ & $40.9(12.2)$ & $37.0(11.9)^{\mathrm{b}}$ \\
\hline $\mathrm{HbA}_{1 \mathrm{c}},(\%)$ & $8.4(1.6)$ & $8.4(1.6)$ \\
\hline Haemoglobin (g/l) & $127(18)$ & $121(18)^{\mathrm{b}}$ \\
\hline Serum potassium (mmol/1) & $4.5(0.5)$ & $4.9(0.4)^{\mathrm{b}}$ \\
\hline $\begin{array}{l}\text { Serum potassium } \geq 5.0 \\
\mathrm{mmol} / 1, n(\%)\end{array}$ & $140(15.1)$ & $187(45.6)^{\mathrm{b}}$ \\
\hline \multicolumn{3}{|l|}{ Treatment, $n(\%)$} \\
\hline Losartan & $416(44.8)$ & $259(63.2)^{b}$ \\
\hline Thiazide diuretics & $161(17.3)$ & $45(11.0)^{\mathrm{b}}$ \\
\hline K-sparing diuretics & $24(2.6)$ & $7(1.7)$ \\
\hline Loop diuretics & $426(45.9)$ & $177(43.2)$ \\
\hline Calcium channel blocker & $679(73.2)$ & $291(71.0)$ \\
\hline$\alpha$-Blockers & $239(25.8)$ & $81(19.8)^{b}$ \\
\hline$\beta$-Blockers & $173(18.6)$ & $76(18.5)$ \\
\hline \multicolumn{3}{|l|}{ Month 6 characteristics } \\
\hline Systolic BP (mmHg) & $149.3(19.8)$ & $150.1(20.4)$ \\
\hline Diastolic BP (mmHg) & $81.2(10.7)$ & $79.3(10.4)^{\mathrm{b}}$ \\
\hline $\begin{array}{l}\text { Urinary ACR (mg/mmol), } \\
\text { median (IQR) }\end{array}$ & $1095(407-22-5)$ & $1228(454-2571)^{\mathrm{b}}$ \\
\hline $\operatorname{eGFR}\left(\mathrm{mlmin}^{-1} 1.73 \mathrm{~m}^{-2}\right)$ & $38.1(14.2)$ & $32.9(13.2)^{\mathrm{b}}$ \\
\hline
\end{tabular}

${ }^{\mathrm{a}}$ Data are presented as means (SD) unless otherwise indicated.

${ }^{\mathrm{b}} p<0.05$ between patients with $\mathrm{K} \geq 5.0 \mathrm{mmol} / \mathrm{l}$ and those with $\mathrm{K}$ $<5.0 \mathrm{mmol} / \mathrm{l}$ at month 6 .

$\mathrm{BP}$, blood pressure; IQR, interquartile range

remained relatively stable during follow-up (Fig. 1). In contrast, in the placebo group, the mean potassium level decreased gradually from $4.62 \mathrm{mmol} / \mathrm{l}$ at baseline to $4.56 \mathrm{mmol} / \mathrm{l}$ at month 6 , and remained relatively stable thereafter.

The percentage of patients with month 6 serum potassium levels $\geq 5.0 \mathrm{mmol} / 1$ and $\geq 5.5 \mathrm{mmol} / 1$ increased from 167 (22.2\%) at baseline to $259(38.4 \%)$ and $22(2.9 \%)$ at baseline to $73(10.8 \%)$ at month 6 , respectively in patients on losartan, while in those on placebo it decreased from 200 (26.2\%) to 


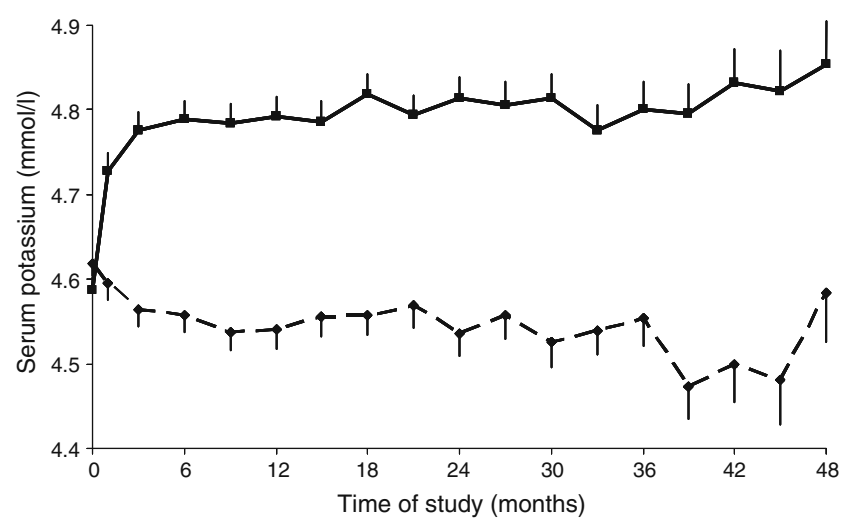

Fig. 1 Mean serum potassium level during follow-up among patients who were assigned to receive losartan or placebo. Bars represent standard errors. Continuous line, losartan; dashed line, placebo

$151(22.8 \%)$ and from $35(4.6 \%)$ to $34(5.1 \%)$, respectively (Fig. 2a, b).

Patients with serum potassium levels $\geq 5.0 \mathrm{mmol} / 1$ at month 6 were more likely to have higher baseline serum potassium levels, higher ACR, lower diastolic blood pressure and lower haemoglobin levels compared with patients with serum potassium $<5.0 \mathrm{mmol} / \mathrm{l}$ (Table 1). The use of losartan was more common, while the use of thiazide diuretics and $\alpha$-blockers was less common in patients with serum potassium $\geq 5.0 \mathrm{mmol} / 1$.

Predictors of incident serum potassium $\geq 5.0 \mathrm{mmol} / \mathrm{l}$ at month 6 In testing in multivariate analysis which baseline variables are related to increased serum potassium $\geq 5.0 \mathrm{mmol} / 1$ at month 6 , we found that the strongest baseline predictors were losartan therapy (OR 2.81; 95\% CI 2.03-3.89) and serum potassium (OR 2.26; 95\% 1.513.37). In contrast, a decreased eGFR was associated with an increased risk of high serum potassium (Table 2).

Month 6 serum potassium and renal outcomes Serum potassium level was associated with a higher risk of the composite renal outcome of DSCR or ESRD. As observed in Fig. 3a, the risk already started to significantly increase

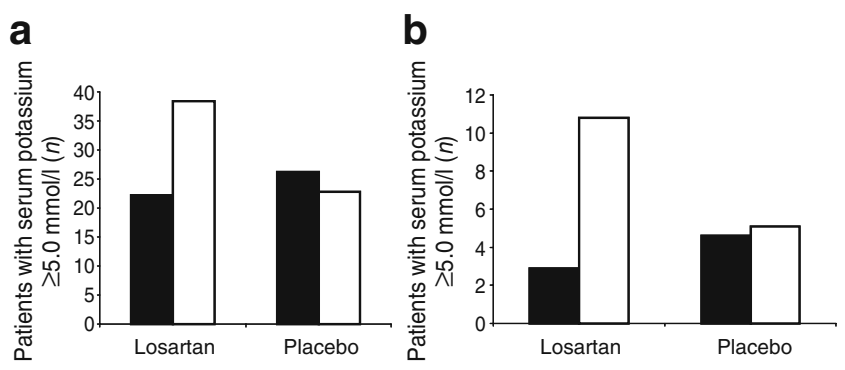

Fig. 2 Proportion of patients with serum potassium $\geq 5.0 \mathrm{mmol} / 1$ (a) and $\geq 5.5 \mathrm{mmol} / \mathrm{l}$ (b) at baseline (black bars) and month 6 (white bars) among patients assigned to losartan and placebo
Table 2 Baseline multivariate predictors of incident drug induced serum potassium $\geq 5.0 \mathrm{mmol} / 1$ at month 6

\begin{tabular}{|c|c|c|c|}
\hline Risk marker & OR $(95 \% \mathrm{CI})$ & $x^{2}$ & $p$ value \\
\hline Losartan treatment & $2.80(2.02-3.88)$ & 38.3 & $<0.001$ \\
\hline Serum potassium $(\mathrm{mmol} / \mathrm{l})$ & $2.30(1.53-3.44)$ & 26.2 & $<0.001$ \\
\hline eGFR, $\left(\mathrm{mlmin}^{-1} 1.73 \mathrm{~m}^{-2}\right)$ & $0.98(0.97-0.99)$ & 6.2 & 0.013 \\
\hline$\alpha$-Blocker use & $0.68(0.46-1.01)$ & 3.6 & 0.058 \\
\hline Loop diuretic use & $0.75(0.53-1.04)$ & 3.0 & 0.085 \\
\hline $\begin{array}{l}\text { Month } 6 \text { change eGFR } \\
\left(\mathrm{mlmin}^{-1} 1.73 \mathrm{~m}^{-2}\right)\end{array}$ & $1.02(0.99-1.05)$ & 2.9 & 0.086 \\
\hline Age (years) & $1.02(0.99-1.04)$ & 2.2 & 0.141 \\
\hline Haemoglobin (g/l) & $0.94(0.85-1.04)$ & 1.5 & 0.228 \\
\hline $\begin{array}{l}\text { Diastolic blood pressure } \\
(\mathrm{mmHg})\end{array}$ & $0.99(0.98-1.01)$ & 1.3 & 0.252 \\
\hline $\begin{array}{l}\text { Log-transformed ACR, } \\
\log \text { unit } \mathrm{mg} / \mathrm{mmol}\end{array}$ & $1.06(0.89-1.26)$ & 0.4 & 0.541 \\
\hline Thiazide use & $0.82(0.53-1.27)$ & 0.8 & 0.372 \\
\hline
\end{tabular}

Predictors are ordered by decreasing significance based on $\chi^{2}$ values

Presented risk markers were selected for multivariate analysis if an association with serum potassium $\geq 5.0 \mathrm{mmol} / \mathrm{l}$ was demonstrated in univariate analyses. Risk markers are ordered according the $\chi^{2}$ values

from serum potassium $\geq 5.0 \mathrm{mmol} / 1$ and further increased at serum potassium $\geq 5.5 \mathrm{mmol} / \mathrm{l}$ during follow-up (HR 1.39; 95\% CI 1.07-1.80 and HR 1.77; 95\% CI 1.22-2.56, respectively). However several other factors also explained the progressive loss of renal function such as age, eGFR, and ACR. The most important question was therefore whether the progressive nature of renal endpoints in patients with serum potassium $\geq 5.0 \mathrm{mmol} / \mathrm{l}$ is independent of other factors, and most importantly, by the prevailing renal function, as patients with low eGFR are more prone to develop high serum potassium levels. After adjustment for other risk factors, month 6 serum potassium $\geq 5.0 \mathrm{mmol} / 1$ was associated with a $22 \%$ increased risk for developing adverse renal outcomes (HR 1.22; 95\% CI 1.00-1.50). Further analysis revealed that this increased risk was merely attributed to patients with persistent drug-induced serum potassium $\geq 5.0 \mathrm{mmol} / \mathrm{l}$ both at month 6 and month 9 (HR 1.56; 95\% CI 1.09-2.21) (Table 3).

In the second approach we assessed the association between the mean serum potassium level during follow-up with renal outcomes. The relationship between the mean serum potassium level during follow-up displayed a similar pattern with renal outcomes as the month 6 serum potassium level (Fig. 3b). After controlling for potential confounders, the analyses revealed that patients who achieved a mean serum potassium $\geq 5.0 \mathrm{mmol} / 1$ during follow-up had a $43 \%$ higher risk of the composite endpoint of DSCR or ESRD (HR 1.36; 95\% CI 1.11-1.67).

The sensitivity analysis in 712 patients matched per propensity score showed similar detrimental effects of 

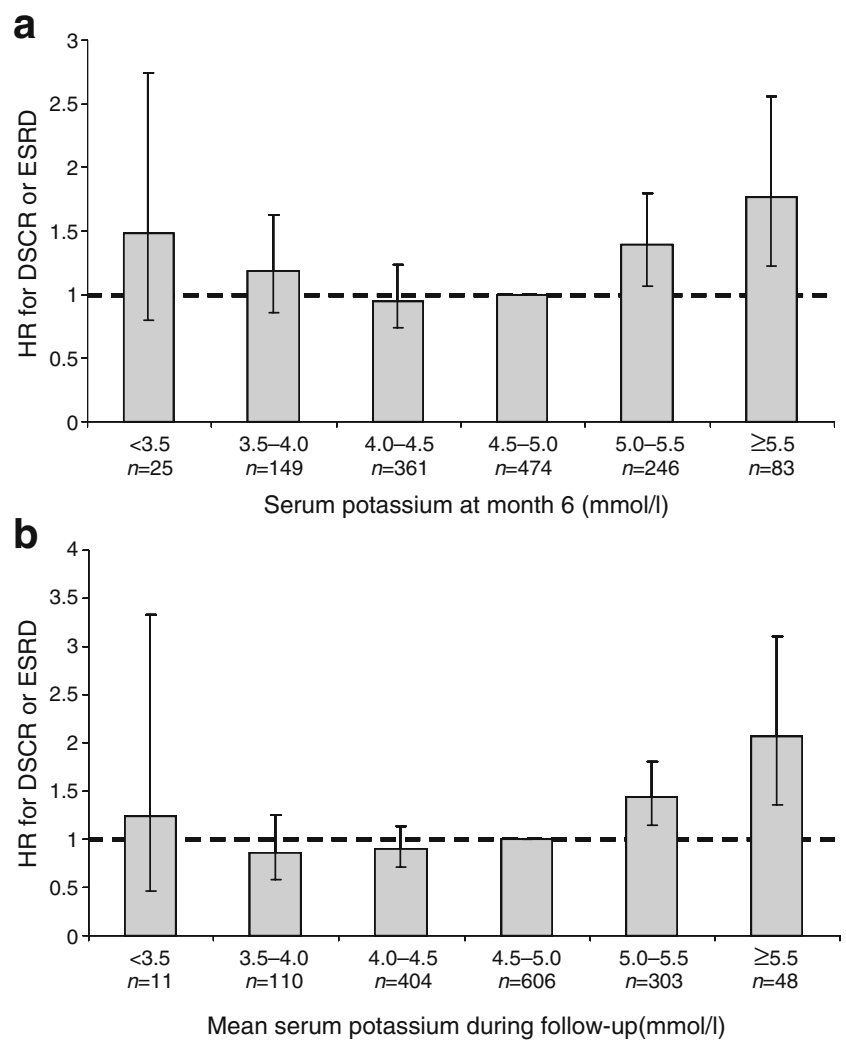

Fig. 3 Month 6 serum potassium level (a) and mean serum potassium (b) and the risk for the composite renal endpoint (DSCR or ESRD). Bars represent $95 \%$ CI

increased serum potassium $\geq 5.0 \mathrm{mmol} / 1$ on renal outcomes (HR 1.32; 1.03-1.70). There was no heterogeneity between increased serum potassium and eGFR $(p=0.132)$.

Effect of serum potassium $\geq 5.0 \mathrm{mmol} / \mathrm{l}$ on the renoprotection induced by losartan To examine to what extent the increase in potassium influences the renoprotective effect afforded by losartan, we analysed the impact of an increase in serum potassium on the losartan treatment effect. When the treatment effect on losartan was adjusted for the residual potassium level (last potassium level measured prior to the renal endpoint), the treatment effect of losartan on the DSCR or ESRD endpoint increased from 21\% (6-34\%) to $35 \%(20-48 \%)$. This finding suggests that the effect of losartan on serum potassium offsets the renoprotective effect of losartan.

\section{Discussion}

In this study, we showed that treatment with losartan increased the serum potassium concentration. We furthermore demonstrated that the occurrence of high serum potassium levels increased the risk of adverse renal outcomes and counteract the beneficial renoprotective effects of losartan. The increase in the renal risk appeared to be independent of other important renal risk factors, such as blood pressure, eGFR and ACR. Thus, although the RENAAL trial has clearly shown that losartan is a renoprotective drug, under this protection a renal damaging effect is hiding in those individuals in whom losartan induces high serum potassium levels.

The effects of the ARB losartan on serum potassium are in line with other studies. In patients with diabetes, either addition or administration of an ARB increases the incidence of hyperkalaemia, independent of renal function [8]. Also, in patients with heart failure, addition of an ARB or aldosterone antagonist to baseline RAAS inhibitor therapy increases the risk of hyperkalaemia [9, 12]. In contrast, in non-diabetic patients addition of RAASinhibitors poses a minimal risk of hyperkalaemia as long as renal function is relatively preserved [13-17]. It appears that the risk of hyperkalaemia is particularly elevated in patients with underlying predisposing disorders, such as diabetes and renal insufficiency, and in patients who receive combined RAAS therapy.

The mechanism via which ARB treatment induces elevations in serum potassium levels has already been

Table 3 Persistent and single elevated serum potassium $\geq 5.0 \mathrm{mmol} / 1$ and their association with the risk for DSCR or ESRD ${ }^{\mathrm{a}}$

\begin{tabular}{|c|c|c|c|}
\hline Risk factors & HR $(95 \% \mathrm{CI})$ & $x^{2}$ & $p$ value \\
\hline $\begin{array}{l}\text { Drug induced persistent }{ }^{\mathrm{b}} \text { serum } \\
\text { potassium } \geq 5.0 \mathrm{mmol} / 1 \\
\text { (month } 6 \text { and } 9 \text { ) }\end{array}$ & $1.54(1.07-2.22)$ & 5.4 & 0.020 \\
\hline $\begin{array}{l}\text { Single }^{\mathrm{c}} \text { elevated serum potassium } \\
\geq 5.0 \mathrm{mmol} / 1 \text { (month } 6 \text { or } 9)\end{array}$ & $1.26(0.93-1.70)$ & 2.2 & 0.142 \\
\hline Age & $0.97(0.96-1.00)$ & 2.3 & 0.126 \\
\hline Race (reference: White) & - & - & - \\
\hline Black & $2.13(146-3.10)$ & 15.6 & $<0.001$ \\
\hline Asian & $1.42(1.01-1.99)$ & 4.0 & 0.046 \\
\hline Other & $1.62(1.18-2.21)$ & 9.0 & 0.003 \\
\hline eGFR & $0.96(0.95-0.97)$ & 46.6 & $<0.001$ \\
\hline Systolic blood pressure & $1.01(1.00-1.02)$ & 7.2 & 0.008 \\
\hline Diastolic blood pressure & $0.99(0.98-1.01)$ & 1.4 & 0.233 \\
\hline ACR & $3.75(3.12-4.51)$ & 196.8 & $<0.001$ \\
\hline Treatment (losartan/placebo) ${ }^{\mathrm{d}}$ & $0.92(0.71-1.20)$ & 0.4 & 0.538 \\
\hline
\end{tabular}

${ }^{\mathrm{a}}$ Essentially similar results were obtained for the individual components of the endpoint (data not shown)

${ }^{\mathrm{b}}$ Persistent elevated serum potassium defined as drug induced serum potassium $\geq 5.0 \mathrm{mmol} / 1$ at month 6 and 9

${ }^{\mathrm{c}}$ Single elevated measurement defined as serum potassium $\geq 5.0 \mathrm{mmol} / 1$ at month 6 or 9

${ }^{\mathrm{d}}$ There was no interaction between treatment groups and high potassium at month 6 and $9(p=0.284)$ indicating that the association between high potassium and renal outcome are consistent across both treatment groups 
described [6]. In short, potassium excretion is mainly regulated by serum aldosterone and sodium delivery to the distal nephron. Blocking the effects of angiotensin II by RAAS inhibitors decreases aldosterone production and consequently induces hyperkalaemia. Patients with diabetes are particularly susceptible to the hyperkalaemic effects of RAAS inhibitors as their RAAS activity is already suppressed. Several factors may account for this, such as an impaired conversion of pro-renin to renin [18] or volume expansion with subsequent increase in circulating atrial natriuretic peptide levels and suppression of plasma renin activity [19].

In previous studies no data are available on the effect of high serum potassium levels on renal outcomes. Our study showed for the first time that increased serum potassium concentrations $\geq 5.0 \mathrm{mmol} / 1$ is associated with a clearly increased risk of DSCR or ESRD, independent of renal function and other important predictors of renal outcomes. The pathophysiological mechanism whereby increased serum potassium levels affect renal outcomes is not well known. It is likely that individuals with persistent drug induced hyperkalaemia are resistant against the kaliuretic effects of aldosterone. It has indeed been shown that the trans-tubular potassium gradient, as measure for aldosterone bioactivity with respect to its kaliuretic response, is decreased in individuals with drug induced hyperkalaemia despite increased plasma aldosterone levels [20]. Consequently, these individuals are continuously exposed to the deleterious effects of aldosterone on renal tissue. Another potential mechanism could be that a vicious cycle exits between renal function and potassium levels that usually takes place in disorders that affect both tubular dysfunction and release of renin. On the one hand, a decrease in renal perfusion and the start of tubulointerstitial damage may impair renal potassium excretion, even though renal function is only mildly depressed. This situation may lead to an imbalance in renal potassium/sodium handling that may further damage the tubules, thereby subsequently contributing to a further decline in renal function [7].

Several reports have drawn attention to spurious hyperkalaemia (pseudohyperkalaemia) as a common problem in clinical care [21, 22]. The reasons for spurious hyperkalaemia are multiple, such as inappropriate phlebotomy technique (e.g. requesting patient to fist clench to facilitate venesection), improper sample storage (i.e. cold storage or too long storage causing deterioration of the sample specimen) or contamination with anticoagulant from another sample (ethylene diamine tetra-acetic acid [EDTA]contamination) $[21,22]$. As it is unlikely that individuals with a single erroneous potassium measurement are at increased risk, we classified patients in those who had persistent high serum potassium levels at month 6 and 9. As expected, the increased risk for renal outcomes was particularly marked in individuals with high serum potassium at both visit 6 and 9 . This implies that elevation in serum potassium level needs particular attention and appropriate management if it is confirmed at a follow-up visit. In addition, our data on the relationship between the mean potassium level during follow-up, which reflects the exposure to a high serum potassium load during a definitive period of time more accurately than a single value, and renal outcomes displayed a similar association between increased serum potassium and adverse renal outcomes. These results are in clear contrast to a recent report from Weir et al. who suggested that the changes in serum potassium concentration observed during RAAS therapy are unlikely to be clinically significant [23]. We recommend not down-playing modest changes in serum potassium as they independently indicate increased risk for renal outcomes in the long-term.

Hyperkalaemia is usually defined by a serum potassium concentration $\geq 5.5 \mathrm{mmol} / 1$. Our results demonstrated a distinct risk of adverse renal events in not only patients with serum potassium concentration $\geq 5.5 \mathrm{mmol} / \mathrm{l}$, but also in patients with potassium concentrations $\geq 5.0 \mathrm{mmol} / 1$ during follow-up and at month 6 . These results have important consequences for clinical practice as they indicate that the risk for renal events already starts to increase within ranges that are currently considered to be normal. Particular caution is needed when prescribing a second RAAS agent as the combination of RAAS inhibitors may lead to even higher serum potassium levels [24, 25]. In patients with high potassium levels at start of ARB therapy, it may be initiated with a low dose, and increased to a higher dose if serum potassium levels do not increase above a therapeutic threshold.

Would improved management of high serum potassium levels lead to better renal outcomes associated with RAAS blockade? Our study does not directly answer this question. However, when we adjusted the treatment effects by the residual serum potassium levels measured prior to the renal endpoint the renoprotective effects associated with losartan use markedly improved. It is therefore tempting to speculate that management of high serum potassium levels improves the renoprotective effects of losartan. Further prospective randomised controlled trials are needed to confirm this finding.

Our study has some limitations. First, this is a post-hoc analysis, and as such may be subject to confounding. To control for confounding we adjusted for a wide range of clinical variables, both at baseline and follow-up. It is nevertheless possible that residual confounding remained even in our multivariate adjusted analysis. Also, we performed two additional sensitivity analyses matching patients on their eGFR and propensity score to ensure that renal events are independent of important predictors of increased serum potassium. Second, although the RENAAL trial included a broad range of patients with type 2 diabetes 
and nephropathy, the findings cannot be extrapolated to other populations.

In conclusion, in this study we found that treatment with the ARB losartan is associated with a high risk of serum potassium level elevation in patients with type 2 diabetes and nephropathy. This elevated serum potassium level is in turn associated with an increased risk of renal outcomes and offsets the renoprotective effects of losartan. Whether additional management of elevated serum potassium would further increase the renal protective properties of losartan is an important clinical question.

Acknowledgements We acknowledge the supportive role of all RENAAL investigators, support staff and participating patients.

Duality of interest The RENAAL study was funded by Merck \& Co. B.M. Brenner, M.E. Cooper, D. de Zeeuw, H-H. Parving have received financial support from Merck for their participation in the Steering Committee. S. Shahinfar has been an employee of Merck.

Open Access This article is distributed under the terms of the Creative Commons Attribution Noncommercial License which permits any noncommercial use, distribution, and reproduction in any medium, provided the original author(s) and source are credited.

\section{References}

1. Keane WF, Brenner BM, de Zeeuw D et al (2003) The risk of developing end-stage renal disease in patients with type 2 diabetes and nephropathy: the RENAAL study. Kidney Int 63:1499-1507

2. Raine AE (1993) Epidemiology, development and treatment of end-stage renal failure in type 2 (non-insulin dependent) diabetic patients in Europe. Diabetologia 36:1099-1104

3. Brenner BM, Cooper ME, de Zeeuw D et al (2001) Effects of losartan on renal and cardiovascular outcomes in patients with type 2 diabetes and nephropathy. N Engl J Med 345:861-869

4. Lewis EJ, Hunsicker LG, Clarke WR et al (2001) Renoprotective effect of the angiotensin-receptor antagonist irbesartan in patients with nephropathy due to type 2 diabetes. N Engl J Med 345:851-860

5. Desai A (2008) Hyperkalemia associated with inhibitors of the renin-angiotensin-aldosterone system: balancing risk and benefit. Circulation 118:1609-1611

6. van Nieuwkoop C, Ijpelaar DH, Bolk JH (2007) Treating proteinuria in a diabetic patient despite hyperkaliemia due to hyporeninaemic hypoaldosteronism. Neth J Med 65:75-77

7. Palmer BF (2004) Managing hyperkalemia caused by inhibitors of the renin-angiotensin-aldosterone system. N Engl J Med 351: 585-592

8. Takaichi K, Takemoto F, Ubara Y, Mori Y (2007) Analysis of factors causing hyperkalemia. Intern Med 46:823-829

9. Desai AS, Swedberg K, McMurray JJ et al (2007) Incidence and predictors of hyperkalemia in patients with heart failure: an analysis of the CHARM Program. J Am Coll Cardiol 50:19591966
10. Brenner BM, Cooper ME, de Zeeuw D et al (2000) The losartan renal protection study - rationale, study design and baseline characteristics of RENAAL (Reduction of Endpoints in NIDDM with the Angiotensin II Antagonist Losartan). J Renin Angiotensin Aldosterone Syst 1:328-335

11. Kratz A, Ferraro M, Sluss PM, Lewandrowski KB (2004) Case records of the Massachusetts General Hospital. Weekly clinicopathological exercises. Laboratory reference values. N Engl J Med 351:1548-1563

12. Pitt B, Bakris G, Ruilope LM, DiCarlo L, Mukherjee R (2008) Serum potassium and clinical outcomes in the Eplerenone PostAcute Myocardial Infarction Heart Failure Efficacy and Survival Study (EPHESUS). Circulation 118:1643-1650

13. Weinberg JM, Appel LJ, Bakris G et al (2009) Risk of hyperkalemia in nondiabetic patients with chronic kidney disease receiving antihypertensive therapy. Arch Intern Med 169:15871594

14. Mitterbauer C, Heinze G, Kainz A, Kramar R, Horl WH, Oberbauer R (2008) ACE-inhibitor or AT2-antagonist therapy of renal transplant recipients is associated with an increase in serum potassium concentrations. Nephrol Dial Transplant 23:1742-1746

15. Maddirala S, Khan A, Vincent A, Lau K (2008) Effect of angiotensin converting enzyme inhibitors and angiotensin receptor blockers on serum potassium levels and renal function in ambulatory outpatients: risk factors analysis. Am J Med Sci 336: $330-335$

16. Han SW, Won YW, Yi JH, Kim HJ (2007) No impact of hyperkaliemia with renin-angiotensin system blockades in maintenance haemodialysis patients. Nephrol Dial Transplant 22:11501155

17. Einhorn LM, Zhan M, Hsu VD et al (2009) The frequency of hyperkalemia and its significance in chronic kidney disease. Arch Intern Med 169:1156-1162

18. Lush DJ, King JA, Fray JC (1993) Pathophysiology of low renin syndromes: sites of renal renin secretory impairment and prorenin overexpression. Kidney Int 43:983-999

19. Clark BA, Brown RS, Epstein FH (1992) Effect of atrial natriuretic peptide on potassium-stimulated aldosterone secretion: potential relevance to hypoaldosteronism in man. J Clin Endocrinol Metab 75:399-403

20. Mayan H, Kantor R, Farfel Z (2001) Trans-tubular potassium gradient in patients with drug-induced hyperkalemia. Nephron 89:56-61

21. Bailey IR, Thurlow VR (2008) Is suboptimal phlebotomy technique impacting on potassium results for primary care? Ann Clin Biochem 45:266-269

22. Cornes MP, Ford C, Gama R (2008) Spurious hyperkaliemia due to EDTA contamination: common and not always easy to identify. Ann Clin Biochem 45:601-603

23. Weir MR, Rolfe M (2010) Potassium homeostasis and reninangiotensin-aldosterone system inhibitors. Clin J Am Soc Nephrol 5:531-548

24. Vogt L, Navis G, de Zeeuw D (2005) Individual titration for maximal blockade of the renin-angiotensin system in proteinuric patients: a feasible strategy? J Am Soc Nephrol 16(Suppl 1):S53S57

25. Frimodt-Moller M HNA, Strandgaard S, Kamper AL (2009) Feasibility of combined treatment with enalapril and candesartan in advanced chronic kidney disease. Nephrol Dial Transplant 